\title{
Effectiveness of Quality Management System (QMS) on Construction Projects
}

\author{
Behnam Neyestani \\ Email address: behnam_neyestani@dlsu.edu.ph \\ Department of Civil Engineering, De La Salle University, Manila, Philippines.
}

\begin{abstract}
Quality management system (QMS) provides generic guidance and requirements for establishing an appropriate quality management procedure, in order to lower cost, increase productivity, customer's satisfaction, and market share in the organizations since the last twodecade. In construction industry, it can assist the companies to achieve successfully their objectives, and ensure that all phases of construction project consistently meet client's requirements (need). The main aim of this article was to evaluate the impact of QMS implementation on main factors of construction projects in Metro Manila, Philippines. For this intention, the study was conducted an in-depth literature review from different books, journals, and websites, in order to understand profoundly quality management system, identify the characteristics of the vital factors of construction projects, and the findings of empirical studies concerning the effects of QMS on construction projects. Subsequently, a questionnaire was designed based on previous studies and then distributed randomly among the 37 managers with the aim of collecting data. Finally, the analysis of data was accomplished by descriptive statistics to find the results and conclusion. The findings have shown that the implementation of QMS can be affected mostly on customer's satisfaction, followed by cost, and time respectively, while minimum effectiveness of QMS was on scope (quality) through QMS implementation in construction projects in Metro Manila.
\end{abstract}

Keywords: ISO, ISO 9000 Family; Quality Management System (QMS); Construction Projects; Critical Factors; Project Success Criteria, Customer's Satisfaction.

\section{INTRODUCTION}

The majority of the construction companies face many challenges and problems, such as "workmanship defects", delay, and "cost overrun in complementing their projects in all over the world. Since over the past three decades, the globalization and competition have been increasing (Neyestani and Juanzon, 2016). Thus, the globalization and competition are the most important reasons that each construction company needs to improve and correct its system for achieving its objectives by management tools. As the results of studies in 776 projects across seven industries in different countries have showed construction and engineering companies were successfully achieve their goals because of being subject to particularly through planning, analysis and controlling by project management (Zwikael and Smyrk, 2011). Successful project management can be defined as having achieved the project objectives as on time, within cost, and quality (scope) to meet client's requirement (Kerzner, 2010). Quality is the most significant factor in the success of construction projects. But numerous reports have criticized the construction industry, especially in terms of productivity, quality and quality system (Ali and Rahmat, 2010), and the majority of project managers focus on the cost and time instead of quality for construction projects, but the scholars emphasize more attention should be towards quality (Mane and Patil, 2015). Nowadays, quality has not just implicated on products and services in the organizations, it can be related to the process, system, and management as well. Quality of construction project is a general philosophy by which process are carried in a total quality infrastructure (Alberto, 2011). The total quality infrastructure consists of several key pieces. The first, and one of the most important, is the quality system (Juran and 
Godfrey, 1999) as a business management tool. In 1987, the first edition of quality system was introduced by the International Organization for Standardization (ISO) to aim quality and customer's satisfaction improvement.

QMS is included systematic approach, documentation, guidance, and audit that can be a part of every project management processes from the moment the project initiates to the final steps in the project closure phase as well (Aized, 2012). ISO 9001 can improve the efficiency of the processes of the organizations by generic guidance and documentations, and continual improvement through "Plan-Do-Check-Act" (PDCA) methodology to achieve successfully the satisfaction of customer and quality objectives. Unfortunately, most construction companies in developing countries believe establishing QMS is just wasting time and money for consultancy, training, periodical internal and external audit, and certification fee, without any benefit, and it is just useful to have its certification as a market tool. Therefore, the managers often focus on the certification as the primary objective and requirement more than value in the projects, and this kind of the notion can caue inefficient operation and lack of an effective QMS. That is why the most project managers do not usually take a broad enough view of what quality constitutes as QMS, and is not measuring how the project can add value to the client in the short and long term (Madsen, 2013). Some studies showed that lack of support from Top management is the most barrier to implement QMS in construction industry (khattak, and Arshad, 2015). Also, the lack of enough evidence concerning how QMS actually affects on organizational practices and performance (lack of awareness in benefits of QMS) is a big problem to motive owners and managers of construction companies in implementing QMS. Thus, this study was carried out with the aim of evaluating the impact of QMS implementation on main elements of construction project (cost, time, quality/scope) in selected construction companies in Metro Manila, Philippines.

\section{LITERATURE REVIEW}

\section{Overview of QMS (ISO 9000 family)}

ISO (the International Organization for Standardization) is a worldwide federation of national standards bodies (ISO member bodies). Quality system was introduced by ISO on 15, March 1987. ISO is compatible with proprietary approaches to quality management such as those recommended by Deming, Juran, Crosby, and non- proprietary approaches such as TQM, Lean Six Sigma, FMEA, COQ, and other continuous improvement techniques (PMI, 2008). Successful implementation of QMS is to take it as a strategic decision for the organization. The purpose of quality management system can be namely such as reducing possible errors all phases of projects by proper control, finding faults/errors soon, measuring to avoid repeated mistakes, and determining and initiating corrective action/preventive measures (Aized, 2012). According to the latest survey of ISO (2014), 1,609,294 ISO certificates were issued, and the majority of them were belonged to QMS standard or 1,138,155 ISO 9001 certificates issued that met the requirements of QMS under external audit of third-party or Certification Body (UNIDO, 2012). Approximately, 1600 ISO 9001 certificates issued for different industries in the Philippines by 2014.

ISO (technical committee ISO/TC 176) has been published five editions for ISO 9000 certification. The ISO 9000:1987 was included three standards for quality assurance: ISO 9001, ISO 9002, and ISO 9003 for being a model for quality assurance in only final inspection and testing. The first version of QMS standard or ISO 9000:1994 emphasized on quality assurance via preventive actions added. ISO 9001:2000 was integrated ISO 9001, 9002 and 9003 into one standard or ISO 9001 and making new standard, its main aim was to shift from "quality assurance" to "quality management" (UNIDO, 2012). Accordingly, it made a radical change in thinking based on process approach, structure ( 8 clauses), and customer satisfaction. The third version was published in Nov. 2008 with minimal changes made from the 2000 version but greater emphasis on customer focus and satisfaction (ISO, 2010). The main purpose of ISO 9001:2008 is to clarify existing requirements and to improve consistency of approach with other management standards like EMSs. Recently, ISO 9001:2015 ( $5^{\text {th }}$ ed.) was published in Sep. 2015. The latest edition is generated a radical change in thinking based on the identification of risk and risk control, structure with 10 clauses. Furthermore, this version can be integrated much better with other management standards (ISO, 2015d). The ISO 9000 family for QMS is included (ISO, 2010):

- $\quad$ ISO 9000 - Quality management systems — Fundamentals and vocabulary;

- $\quad$ ISO 9001 - Quality management systems - Requirements;

- $\quad$ ISO 9004 - Managing for the sustained success of an organization — A quality management approach, and;

- ISO 19011 - Guidance for internal and external audits of quality management systems.

ISO 9000 or "quality management principles" are a set of fundamental beliefs, norms, rules and values that are accepted as true and can be used as a basis for quality management (ISO, 2015c). It is a framework to guide their organizations towards improved performance. ISO 9000:2005 has eight quality management principles. Recently, new version of quality management principles was published as ISO 9000:2015 that has seven principles only such as (ISO, 
2015c): 1) Customer focus; 2) Leadership; 3) Engagement of people; 4) Process approach; 5) Improvement; 6) Evidence-based decision making, and; 7) Relationship management.

ISO 9001 or "quality management certification" is a standard that sets out the requirements that are generic and are intended to be applicable to all organizations, regardless of their type, size and product provided for quality management system, technical committee of ISO which is TC-176 formulates all the standards of ISO 9001 (khattak, and Arshad, 2015). In ISO 9001:2008, the standard emphasizes more on customer satisfaction through fulfillment of its requirements (Kuen and Zailani, 2007). ISO 9001 does not specify what the objectives relating to "quality" or "meeting customer needs" should be. Instead, it requires organizations to define these objectives themselves and continually improve their processes in order to reach them (ISO, 2015b). All organizations use processes to achieve their objectives, ISO defined process as set of interrelated or interacting activities that use inputs to deliver an intended result (ISO, 2015d). Thus, ISO 9001: 2008 and 2015 both are based on process approach. The intention of the process approach is to increase an organization's effectiveness and efficiency in achieving its defined objectives and customer's satisfaction. Also, it helps the organizations to control the linkages between processes and the interfaces between the functional hierarchies of the organization (ISO, 2008). As can be seen in Table 1, the process approach in ISO 9001:2008 incorporates the PDCA cycle and preventive action-based under the identification and elimination of the root causes of the problems (e.g. errors, defects, lack of adequate process controls) (ISO, 2008), whereas ISO 9001:2015 incorporates the PDCA cycle and "risk-based thinking" (ISO, 2015d). Consequently, the main changes within the ISO 9001:2015 in comparison with ISO 9001:2008 are as follows (IAF, 2015):

1) "The adoption of the HLS as set out in Annex SL;

2) An explicit requirement for risk-based thinking to understanding better process approach;

3) Less emphasis on documents, and fewer prescribed requirements;

4) Increased emphasis on organizational context (Environment);

5) Increased leadership requirements, and;

6) Greater emphasis on achieving desired outcomes to improve customer satisfaction".

Table 1: The interpretation of PDCA methodology in ISO 9001:2008 \& 2015

\begin{tabular}{|c|c|c|}
\hline Version & ISO 9001:2008 (ISO, 2012) & ISO 9001:2015 (ISO, 2015d) \\
\hline Plan & $\begin{array}{l}\text { Establish the objectives and processes necessary to } \\
\text { deliver results in accordance with customer requirements } \\
\text { and the organization's policies. }\end{array}$ & $\begin{array}{l}\text { Set the objectives of the system and processes to } \\
\text { deliver results ("What to do"and "how to do it"). }\end{array}$ \\
\hline Do & Implement the processes. & Implement and control what was planned. \\
\hline Check & $\begin{array}{l}\text { Monitor and measure processes and product against } \\
\text { policies, objectives and requirements for the product } \\
\text { and report the results. }\end{array}$ & $\begin{array}{c}\text { Monitor and measure processes and results against } \\
\text { policies, objectives and requirements and report } \\
\text { results. }\end{array}$ \\
\hline Act & $\begin{array}{l}\text { Take actions to continually improve process } \\
\text { performance. }\end{array}$ & Take actions to improve processes performance. \\
\hline
\end{tabular}

Furthermore, ISO 9001:2008 and 2015 have approximately the same requirements. Table 2 depicts the clauses of two different versions of ISO 9001. The first three clauses of ISO 9001:2008 and 2015 are not applicable in process approach, these clauses just give some essential information related to the requirements of QMS implementation.

Table 2: The comparison between the clauses of ISO 9001:2008 \& 2015

\begin{tabular}{cll}
\hline Clause & \multicolumn{1}{c}{ ISO 9001:2008 } & \multicolumn{1}{c}{ ISO 9001:2015 } \\
\hline $\mathbf{1}$ & Scope & Scope \\
$\mathbf{2}$ & Normative references & Normative references \\
$\mathbf{3}$ & Terms and definitions & Terms and definitions \\
$\mathbf{4}$ & Quality Management System & Context (Environment) of the organization \\
$\mathbf{5}$ & Management Responsibility & Leadership \\
$\mathbf{6}$ & Resource Management & Planning \\
$\mathbf{7}$ & Product Realization & Support \\
$\mathbf{8}$ & Measurement, Analysis and Improvement & Operation \\
$\mathbf{9}$ & & Evaluation \\
$\mathbf{1 0}$ & & Improvement \\
\hline
\end{tabular}


As demonstrated in Figure 1, the framework of ISO 9001:2008 is based on clauses 4 to 8, while ISO 9001:2015 with its unique structure (Annex SL) is begun from 4 to 10 clause. These models also show all the requirements of the International Standard ISO 9001:2008 and 2015, but their frameworks do not determine processes at a detailed level for the organizations. There are five sections in the ISO 9001:2008 indicating activities that need to be considered when the organizations implement the quality management system, such as:

- $\quad$ Overall requirements for the quality management system and documentation (Clause 4);

- Management responsibility, focus, policy, planning and objectives (Clause 5);

- $\quad$ Resource management and allocation (Clause 6);

- $\quad$ Product realization and process management (Clause 7), and;

- $\quad$ Measurement, monitoring, analysis and improvement (Clause 8).

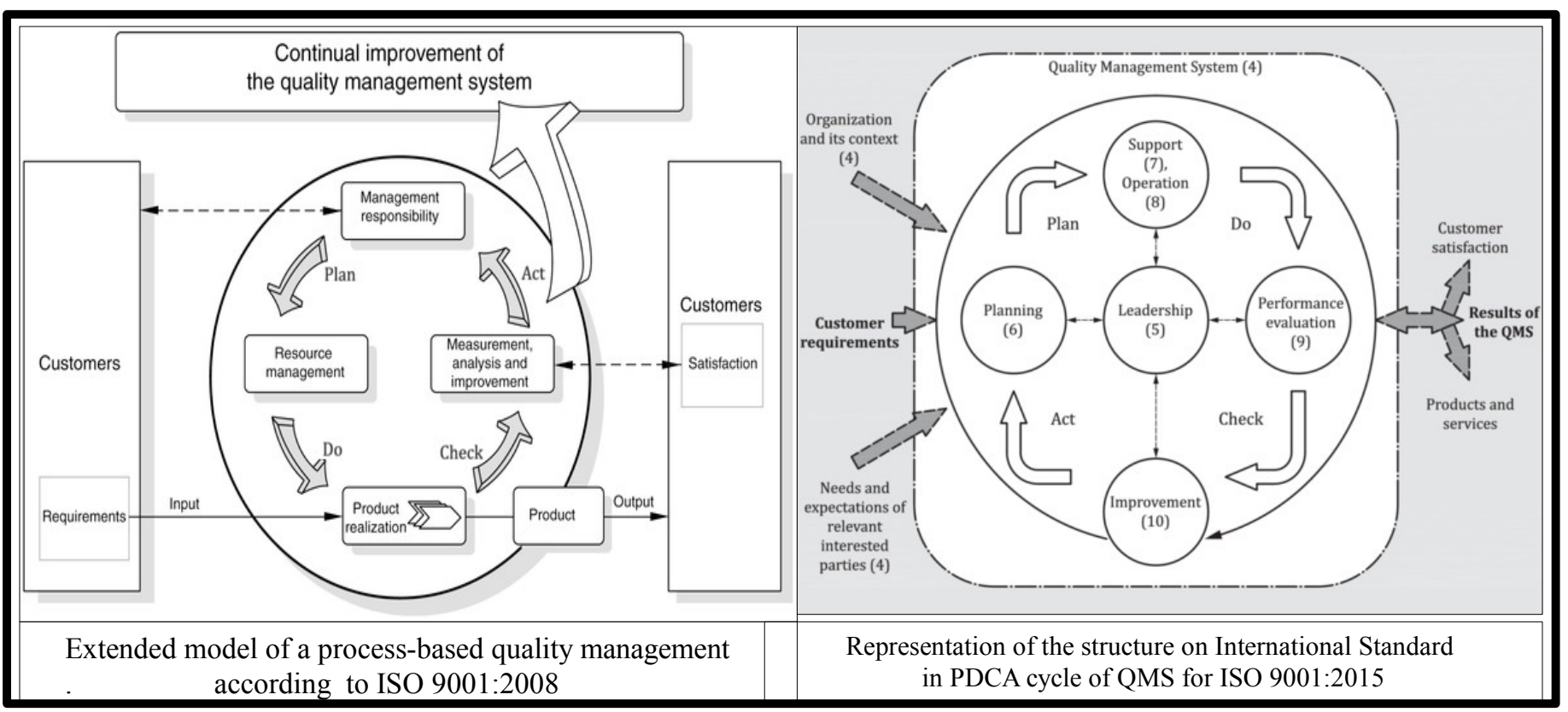

Figure 1. QMS Framework in 2008 and 2015 version

ISO 9004 (2009 version, ${ }^{\text {th }}$ ed.) is another standard of QMS family that leads for the sustained success of an organization. Its emphasis is to address the needs and expectations of all the interested parties of the organization (employees, owners, suppliers, partners, and society in general), in order to achieve sustained success (ISO, 2010). ISO 9004 can guide top management wishes to extend the benefits of ISO 9001 in pursuit of systematic and continual improvement of the organization's overall performance, and it can be used separately or in combination with ISO 9001 (ISO, 2009).

ISO 19011 (2011 version, $2^{\text {nd }}$ ed.) is the only QMS standard, which is exclusive to audit (internal and external) QMS and EMS. Effective audits ensure that an implemented QMS meets the requirements specified in ISO 9001.

\section{Critical Elements within Construction Projects}

Kerzner (2010) explained the project can be considered to be any series of activities and tasks that being completed within certain specifications and consuming resources throughout several functional lines for getting specific objectives. One important aspect of project management is analyzing the information related to the optimum balance among the project's objectives (Hajiagha et al., 2015). These goals should be based on the organization and business objectives to survive in the market and competing with other companies, project management has a significant role to achieve theses objectives. As in any other business, construction projects are aiming to achieve success, and the project success depends on its expectations and how they are fulfilled (Proust, 2011), in order to meet the project requirements 
successfully (PMI, 2008). Extremely, it is essential to identify and focus on construction project objectives as the results of project. A survey was conducted among international organizations in Gaza Strip-Palestine by Enshassi et al. (2014), revealed that the vital factors cooperate to a successful post-evaluation system in construction projects, and these elements are namely cost, time, quality, project efficiency, owner's satisfaction, project effectiveness, safety, risk, $\mathrm{HR}$, communication, procurements, and environment. As presented in Table 3, several authors have researched the subject on project success as critical factors, but the concept of project success is still remained ambiguously defined. it seems that the identification of project success is complicated (Neyestani, 2016). Some authors like Kerzner (2010) specified the project' success as the one that assesses both primary and secondary factors (customer's satisfaction). Primary factors include meeting deadlines, budget limit and the level of expected quality (iron triangle) in construction projects (Varajão et al., 2014), these factors to be criteria for real and balanced achievement of construction projects objectives (Golob et al., 2013).

Table 3. Determining critical elements of the projects by different scholars

\section{Author/s}

Neverauska et al. (2013); Aized (2012)

Kerzner (2010)

PMI (2008)

Rasmy (2008)

Neyestani (2016)

Rezaian (2011)

Varajão et al. (2014)

Neyestani and Juanzon (2016a)

Zwikael and Smyrk (2011); Juran and Godfrey (1999)

Hajiagha et al. (2015); Golob et al. (2013); Madsen, (2013);

Tabish and Jha (2012); Proust (2011); Kuen and Zailani, (2007);

Alberto (2011)

Duggal (2010)
Vital factors of projects

Time, cost, quality (scope), quality of project, and satisfactions and requirements of stakeholders

Time, cost, performance/technology, resources and within good customer relationship

Time, cost, quality, scope, resources, risk, identified requirements, and satisfaction of stakeholders

Time, cost, and customer's requirements

Time, cost, quality and customer's satisfaction

Time, cost, quality, and risk

Time, cost, and scop

Time, cost, quality and productivity

Time, cost, and quality/scope (quantity)

Time, cost, and quality

Stakeholder's and customer's satisfaction, quality, customer/end-user adoption, time, benefits realization (ROI, $\mathrm{NPV}$, and etc.), and meeting governance criteria (health, safety, security and environment (HSSE)

Similarly, a total of 112 questionnaires to large and medium sized organizations in Indian construction industry showed that in successful companies, time (89\%), cost $(79 \%)$ and quality $(74 \%)$ are respectively as most important factors for successful projects (Tabish and Jha, 2012). Therefore, money (cost), time (delay), and quality (process, performance, products, etc.) are reliable, countable, and controllable notions that managers and practitioners are used to considering as main criteria of project success. These three factors are predominant in the management of usual construction projects (Proust, 2011). Doubtlessly, iron triangle is more significant, due to their significant effect on obtained results for being successful in project management that cost and time of the project is minimized while the project quality is maximized (Hajiagha et al., 2015). Also, the critical success processes (CSPs) research model is explained the success project can be affected by: schedule overrun, cost overrun, project performance, and funder's satisfaction (Zwikael and Smyrk, 2011; Neverauskas et al., 2013). Accordingly, the vital elements of the projects can be defined as the organization objectives (Internal factors), and business objectives (external factors) that are related to client's satisfaction (customer's satisfaction) and market, as illustrated in Figure 2. 


\section{Organization objectives}

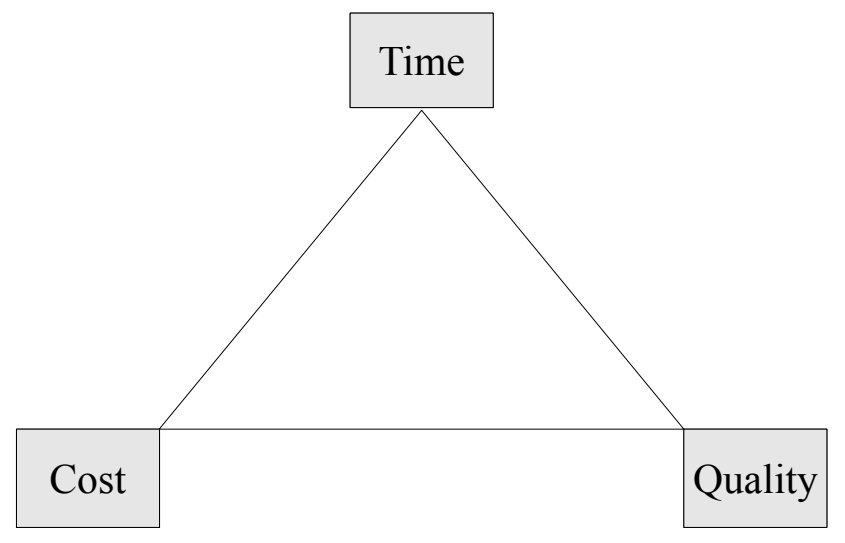

\section{Business objectives}

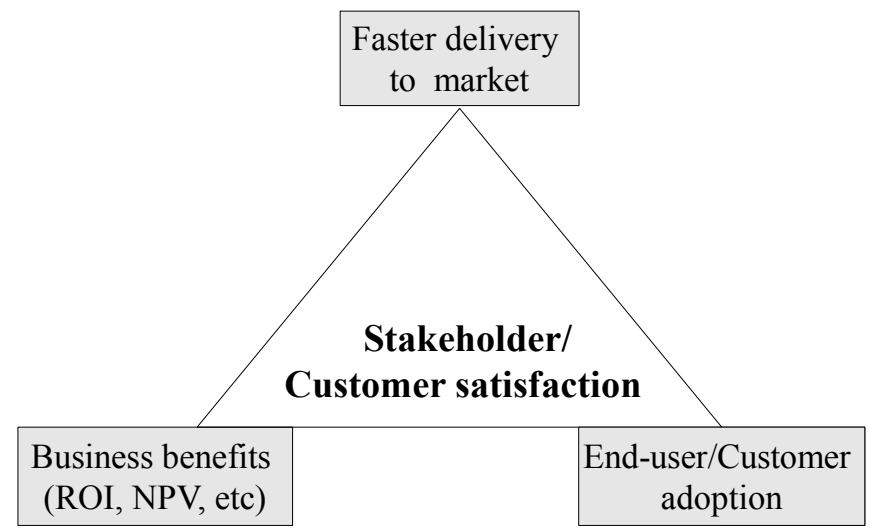

Figure 2. The Reflection of the organization objectives on business objectives (Duggal, 2010)

The involvement and contribution of the client as external factors of project success has essential role during the design phase, to set objectives, to achieve successfully construction project completion (Proust, 2011). Thus, the organization objectives (Internal factors) mirror business objectives (External factors). In implementing successful projects, cost and time should focus to promote business benefits like ROI, NPV, etc., and the benefits of faster delivery or time-to-market. Scope has to mirror end-user adoption, and overall quality has to be balanced with stakeholder/customer satisfaction (Duggal, 2010).

\section{Impact of QMS on Construction Projects}

The QMS is widely used by the organizations for achieving operational and market benefits, it is an optimized standard to upgrade and promote the companies and projects performance. The studies on the impact of QMS reported that these objectives are not always achieved. However, the successful implementation of the ISO 9001 (QMS) standard depends on how the standard is perceived by the companies. As a results, the previous studies on the impact of QMS revealed that the majority of the scholars found the positive effect of QMS on projects (Manders, 2015). For example, a survey by UNIDO (2012) in the Philippines and few countries in Asia, showed that the most of the respondents believed QMS can make excellent (57\%) and good (22\%) influence on the organizations, and the only 3\% stated the negative impacts of QMS on the firms. Likewise, over 54\% had internally motivated reasons (including internal improvement and corporate or top management objective), whilst $39 \%$ had externally motivated reasons (customers, markets or governments pressure) to implement QMS in their organizations. Without doubt, QMS provides the consistency and satisfaction in terms of methods, materials, equipment, etc. in the firms, which can cause they meet the requirements of their customers, and achieve organizational targets in the projects (Aized, 2012), as illustrated in Figure 3.

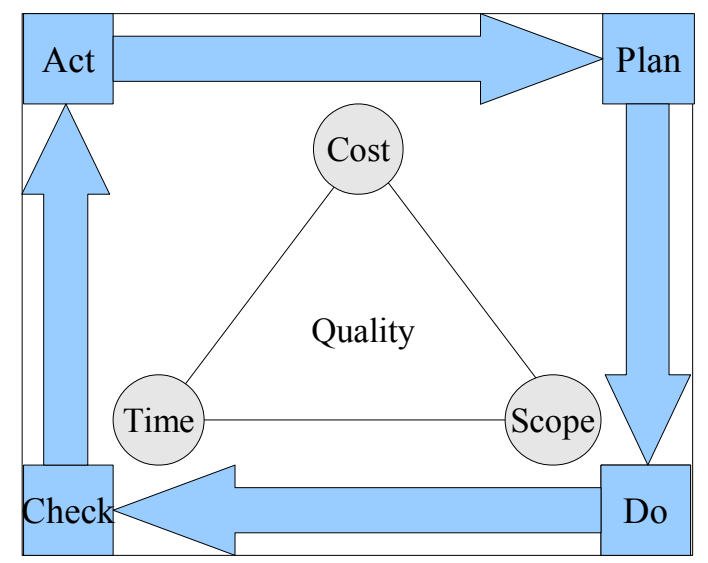

Figure 3. Schematic QMS on organizational targets of projects (iron triangle) (Aized, 2012) 
The mechanism of QMS is simple and efficient to improve project performance, it is included ISO 9001 requirements, and its framework (Process approach and PDCA methodology), which is based on quality management principles (ISO 9000) throughout ISO 9004 guidance to achieve successfully the aims of the organizations, and ISO 19011 audits for ensuring to enforce ISO 9001 requirements accurately. QMS is the part of every project management processes from the moment the project initiates to the final steps in the project closure phase. These processes can improve the performance of project continuously by PDCA methodology.

Many studies and literature have been identified and determined the benefits of QMS that can affect positively on the organizational performance and market in different industries. For example, a survey was performed by Thilakarathne and Chithrangani (2014) for identifying the benefits of implementing QMS in the ISO 9001-certified firms in Sri Lanka, the results of their research indicated that the customer satisfaction, reduces production time, increases quality awareness, improves product/service quality, improves employee productivity, and improves employee relations, were respectively, as most important perceived benefits of the QMS implementation within different companies in Sri Lanka. Based on the findings of several empirical studies, the most aim of QMS standards is to promote the customer's satisfaction, and many studies have been shown that it seems QMS is successful for achieving this aim by improving and stimulating the processes of ISO 9001-certified construction projects. In Malaysian construction companies, the majority of the respondents believed that the functionality and clients' satisfaction are respectively the most influences of QMS implementation into construction projects (Ali, and Rahmat, 2010). In addition, Mane and Patil (2015) found the $90 \%$ of the respondents asserted customer satisfaction and $80 \%$ client satisfaction are the most important aspect for maintaining QMS for construction projects in India.

\section{RESEARCH METHODOLOGY}

\section{Research Design}

As a descriptive study, this research was designed to evaluate effectiveness of QMS implementation on the construction projects based on descriptive methods. Thus, the literature review was first carried out to understanding the topic, and the concepts of the study, in order to develop an appropriate survey questionnaire for obtaining data from the construction projects. The questions were designed on the basis of literature review and preliminary studies. Then the questionnaires were randomly distributed among the respondents working in ISO 9000-certified construction companies in Metro Manila, Philippines.

\section{Data Collection}

The data sources were categorized to prime sources, and secondary sources. Prime sources provide original data for this research. The purposive and convenience sampling method was used in choosing the respondents. Participants in the study were managers in different levels, areas, and specialists within the construction companies. Totally, the 37 usable questionnaires were collected, and used in the statistical analysis. The secondary sources were from journals, books, articles, and journals published, to identify data about the research topic, and likewise to conduct study for further details in the research.

\section{Questionnaire survey}

The questionnaire was used as the primary tool for collecting data. Using the questionnaire can help the researcher/s to collect data faster and cheaper than any other instrument. In this study, the survey questionnaire was divided into two main parts: Part I is related to the general information (demographic characteristics) of the respondents. Part II is focused on the evaluation of the effectiveness of QMS implementation on vital factors of construction projects, this part including the four sections, and each section regarding the effectiveness of QMS implementation on one of the critical element in the construction project (time, cost, quality/scope, and customer's satisfaction). The questions asked were closed-ended questions with a five point Likert rating scale. Furthermore, the questionnaires were personally distributed and retrieved by the researcher to target respondents. The completed questionnaires were collected from them. Also, the confidentiality and anonymity of the participants were protected, for this matter their names were not required on the questionnaires.

\section{Data analysis}

The data was analyzed based on descriptive statistics, the designed questionnaire could let the respondents give their responses corresponding their personal experiences and opinions, to the different variables by point Likert scale (e.g. a scale from 1 to 5, strongly disagreement $=1$, to Strongly agreement $=5$ ). Likert scales are proper and widely used in opinion measurement with scale ranging. The results of the questionnaires being analyzed in this study by using 
SPSS (Statistical Package for the Social Sciences) Version 17 software. So, SPSS by several statistical techniques were employed to measure and analyze the level of importance of the factors, and mean comparison in this study.

\section{DATA ANALYSIS, RESULTS AND DISCUSSION}

\section{Background of Respondents}

The findings of this study were based on 37 respondents in top, medium and lower level management working in different construction companies, which classified as AAA or large-scale in Metro Manila. Table 4 to 7 are presented concerning the results of the respondents' profile. In general, the majority of the managers in construction projects are Male (84\%), the only $16 \%$ of the respondents were Female, as shown in Table 4.

Table 4. Distribution of the respondents according to gender

\begin{tabular}{ccc}
\hline Gender group & Frequency & $\%$ \\
\hline Male & 31 & 84 \\
Female & 6 & 16 \\
\hline
\end{tabular}

Table 5 shows the profile of the respondents classified according to age. As shown, the grouping consists of fiveage brackets distribution. There is no any respondent under 20 years, nine (9) or $24 \%$ of the respondents, within age bracket from $20-29$, sixteen (16) or $43 \%$ within age bracket from $30-39$, eight (8) or $22 \%$ within age bracket from $40-49$, and also five (4) or $11 \%$ within age bracket from 50 or above.

Table 5. Distribution of the respondents according to group age

\begin{tabular}{ccc}
\hline Year & Frequency & $\%$ \\
\hline Below 20 & 0 & 0 \\
$20-29$ & 9 & 24 \\
$30-39$ & 16 & 43 \\
$40-49$ & 8 & 22 \\
50 and above & 4 & 11 \\
\hline
\end{tabular}

Regarding time length of QMS implementation in the construction companies, the most of the respondents (about thirty three (33) or $89 \%$ ) were belonged to the organizations, which have been implemented QMS for 3 years or between 3 years and above. The rest is belonged to those companies have been performed QMS for 1 year or between 1 and 3 years in their firms, as reported in Table 6.

Table 6. Distribution of the respondents according to time length of QMS implementation in the construction company of respondent

\begin{tabular}{ccc}
\hline Year & Frequency & $\%$ \\
\hline Below 1 year & 0 & 0 \\
Between 1 and 3 years & 4 & 11 \\
Between 3 and 5 years & 8 & 22 \\
Between 5and 8 years & 13 & 35 \\
Between 8 and 10 years & 6 & 16 \\
10 and above & 6 & 16 \\
\hline
\end{tabular}

In terms of the level of the respondent's knowledge regarding QMS implementation, seventeen (17) or 46\%, and eleven (11) or $30 \%$ of the respondents had moderate and high level of knowledge about QMS respectively. The only, nine (9) or $24 \%$ of them possessed knowledge at low level, as indicated in Table 7. 
Table 7. Distribution of the respondents according to level of respondent's knowledge in QMS (ISO 9001: 2008)

\begin{tabular}{ccc}
\hline Level of your knowledge in QMS (ISO 9001: 2008) & Frequency & $\%$ \\
\hline Low level & 9 & 24 \\
Moderate level & 17 & 46 \\
High level & 11 & 30 \\
\hline
\end{tabular}

\section{Descriptive Statistics Analysis (Effectiveness of QMS on vital factors of construction projects)}

Table 8 to 11 are presented the mean scores and the rankings from the results of evaluating the effectiveness of QMS implementation on quality/scope, time, cost, and customer's satisfaction respectively in the projects within largescale (AAA) construction companies respectively. As can be seen from Table 8, the majority of the respondents scored "quality awareness improvements", "enhanced involvement of people in improvement activities", and "being effective in quality assurance process" as three most effectiveness of QMS on quality/scope in construction projects in selected large-scale construction firms. The average of mean scores of quality/scope is 3.51 representing the impact of QMS on quality/scope is at 4 level.

Table 8. Descriptive statistics analysis regarding the effectiveness of QMS on quality/scope

\begin{tabular}{|c|c|c|c|c|}
\hline No. & Question & $\begin{array}{l}\text { Average } \\
\text { Index }\end{array}$ & Mode & Rank \\
\hline 1 & $\begin{array}{l}\text { Project scope can match with the project proposal and compliance with contract } \\
\text { specifications }\end{array}$ & 3.38 & 3 & 11 \\
\hline 2 & Being effective in quality assurance process and project audits & 3.65 & 4 & 3 \\
\hline 3 & Product defect rate decreases & 3.27 & 3 & 12 \\
\hline 4 & $\begin{array}{l}\text { Quality awareness improvements and understanding the quality objectives in the } \\
\text { organization }\end{array}$ & 3.78 & 4 & 1 \\
\hline 5 & Non-conformities decrease & 3.43 & 3 & 9 \\
\hline 6 & Product and service quality improvement & 3.49 & 3 & 7 \\
\hline 7 & Contribution to achieving defined objectives for the project in construction & 3.4 & 3 & 10 \\
\hline 8 & Accuracy and presentation of the work by improving quality assurance and control & 3.46 & 3 & 8 \\
\hline 9 & Increased effectiveness and efficiency in meeting the organization's quality objectives & 3.54 & 4 & 5 \\
\hline 10 & $\begin{array}{l}\text { Improved capability to project scope statement, requirements documentation, and project } \\
\text { plan }\end{array}$ & 3.38 & 3 & 11 \\
\hline 11 & Enhanced involvement of people in improvement activities & 3.68 & 4 & 2 \\
\hline 12 & Consistent outcomes, measured and monitored to approach expected level of quality & 3.51 & 4 & 6 \\
\hline 13 & Defining procedures that identifies current practices are obsolete or inefficient & 3.62 & 4 & 4 \\
\hline \multirow[t]{2}{*}{14} & QMS Procedures ensure corrective action is taken whenever defects occur & 3.49 & 3 & 7 \\
\hline & Total & 3.51 & 4 & --- \\
\hline
\end{tabular}

Notes: Level of the effectiveness QMS on: $5=$ Strongly Agree $(4.51-5.00), 4=$ Agree $(3.51-4.50), 3=$ Neutral $(2.51-3.50), 2=$ Disagree $(1.51$ $-2.50), 1=$ Strongly disagree $(<1.50)$.

Table 9 is reported the highest ranking of the impact of QMS on time length of project completion is "the reduction delay by improving communication", second is "the reduction delay by a well-managed supply chain", and ranked third is "the project completion corresponding proposed implementation timeliness", according to the responses of the respondents. Meanwhile, the average of mean scores of theses questions was 3.6 representing the impact of QMS on time length is at 4 level. 
Table 9. Descriptive statistics analysis regarding the effectiveness of QMS on time

\begin{tabular}{|c|c|c|c|c|}
\hline No. & Question & $\begin{array}{l}\text { Average } \\
\text { Index }\end{array}$ & Mode & Rank \\
\hline 1 & $\begin{array}{l}\text { Meeting proposed implementation timeliness with actual timeliness of the project } \\
\text { completion }\end{array}$ & 3.73 & 4 & 3 \\
\hline 2 & Improved project delivery time & 3.65 & 4 & 4 \\
\hline 3 & Ability to help and solve problems of the project completion & 3.27 & 3 & 9 \\
\hline 4 & Reduction of delay as a result of turn over and rework & 3.65 & 4 & 4 \\
\hline 5 & Reduction of delay as a result of errors and change of scope by owners & 3.51 & 4 & 6 \\
\hline 6 & More reliable construction project scheduling and delivery & 3.65 & 4 & 4 \\
\hline 7 & Reduction of delay that are related of failure, shortage, and delivery of the materials & 3.46 & 3 & 7 \\
\hline 8 & Reduction of delay as a result of lack of communication between parties & 3.97 & 4 & 1 \\
\hline 9 & Reduction of delay as a result of unnecessary and without reason of inspections & 3.54 & 4 & 5 \\
\hline 10 & Enhanced ability to anticipate project completion time, delay and its reasons & 3.41 & 3 & 8 \\
\hline 11 & $\begin{array}{l}\text { A well-managed supply chain that provides a stable flow of goods and services to } \\
\text { prevent delay }\end{array}$ & 3.86 & 4 & 2 \\
\hline \multirow[t]{2}{*}{12} & Documented procedures are easier for the employees to follow toward reduction time & 3.65 & 4 & 4 \\
\hline & Total & 3.6 & 4 & --- \\
\hline
\end{tabular}

Notes: Level of the effectiveness QMS on: $5=$ Strongly Agree $(4.51-5.00), 4=$ Agree $(3.51-4.50), 3=$ Neutral $(2.51-3.50), 2=$ Disagree

$(1.51-2.50), 1=$ Strongly disagree $(<1.50)$.

In terms of the effectiveness of QMS on cost, Table 10 revealed that the most respondents answered "realizing the defects earlier and are corrected at a lower cost", "optimizing performance", and "a well-managed supply chain" as the most important effectiveness of QMS on the factors of the projects' costs respectively. In addition, the total mean values of these items was 3.65 indicating that the effect of QMS on the expenses of the construction projects is at 4 level.

Table 10. Descriptive statistics analysis regarding the effectiveness of QMS on projects' costs

\begin{tabular}{|c|c|c|c|c|}
\hline No. & Question & $\begin{array}{l}\text { Average } \\
\text { Index }\end{array}$ & Mode & Rank \\
\hline 1 & $\begin{array}{l}\text { To effectively resolve problems of construction project without changes on the amount } \\
\text { of project budget }\end{array}$ & 3.35 & 3 & 8 \\
\hline 2 & $\begin{array}{l}\text { Business outputs are tracked and measured, which means areas of waste and duplication } \\
\text { can be identified and eliminated. }\end{array}$ & 3.65 & 4 & 4 \\
\hline 3 & $\begin{array}{l}\text { Optimized cost on communication and follow-up of assigned tasks to construction } \\
\text { project resources cheaper and easier }\end{array}$ & 3.49 & 3 & 6 \\
\hline 4 & Increased ROI and profit can be caused reduction of cost & 3.57 & 4 & 5 \\
\hline 5 & $\begin{array}{l}\text { Optimizing performance can reduce expenses by efficient process management and } \\
\text { resources }\end{array}$ & 3.9 & 4 & 2 \\
\hline 6 & $\begin{array}{l}\text { Lower production costs because of fewer nonconforming products, less rework, lowered } \\
\text { rejection rates, streamlined processes and fewer mistakes }\end{array}$ & 3.46 & 3 & 7 \\
\hline 7 & Realizing the defects earlier and are corrected at a lower cost & 4 & 4 & 1 \\
\hline \multirow[t]{2}{*}{8} & A well-managed supply chain can reduce expenses & 3.76 & 4 & 3 \\
\hline & Total & 3.65 & 4 & ---- \\
\hline
\end{tabular}

Notes: Level of the effectiveness QMS on: $5=$ Strongly Agree $(4.51-5.00), 4=$ Agree $(3.51-4.50), 3=$ Neutral $(2.51-3.50), 2=$ Disagree $(1.51-2.50), 1=$ Strongly disagree $(<1.50)$.

Table 11 reported, the most respondents scored "increasing business benefits", as most significant impact of QMS on the customer's and client's satisfaction. Second is "decreased in client's complaints, improved customer loyalty, Improved common understanding of goals and values among interested parties". Ranked third was related to "improved customers relationship, communication, and reporting". Also, the average of mean scores of customer's satisfaction was about 3.86, which revealed that the effectiveness of QMS on customer's satisfaction is at 4 level. 
Table 11. Descriptive statistics analysis regarding the effectiveness of QMS on client's satisfaction

\begin{tabular}{|c|c|c|c|c|}
\hline No. & Question & $\begin{array}{c}\text { Average } \\
\text { Index }\end{array}$ & Mode & Rank \\
\hline 1 & Decreased in client's complaints & 3.92 & 4 & 2 \\
\hline 2 & Improved customers relationship, communication, and reporting & 3.9 & 4 & 3 \\
\hline 3 & Enhanced reputation of the organization and quality image to justify clients & 3.51 & 4 & 6 \\
\hline 4 & Efficient way for conforming to the requirements of construction project & 3.86 & 4 & 4 \\
\hline 5 & Increasing business benefits (ROI, NPV, etc) & 4.08 & 4 & 1 \\
\hline 6 & Improved assessment of process performance and ability to achieve client's satisfaction & 3.86 & 4 & 4 \\
\hline 7 & Improved customer loyalty & 3.92 & 4 & 2 \\
\hline 8 & Improved common understanding of goals and values among interested parties & 3.92 & 4 & 2 \\
\hline \multirow[t]{2}{*}{9} & Processes are in place to track and resolve issues quickly and effectively & 3.81 & 4 & 5 \\
\hline & Total & 3.86 & 4 & --- \\
\hline
\end{tabular}

Notes: Level of the effectiveness QMS on: $5=$ Strongly Agree $(4.51-5.00), 4=$ Agree $(3.51-4.50), 3=$ Neutral $(2.51-3.50), 2=$ Disagree $(1.51-2.50), 1=$ Strongly disagree $(<1.50)$.

In general, Table 12 is presented a summary of the standard deviations, importance index values and the rankings regarding the impact of QMS on critical factors of construction projects within ISO 9001-certified construction companies in Metro Manila, Philippines. From the findings, the customer's satisfaction is one of the business objectives that obtained the highest ranking by the respondents, Therefore, the most effectiveness of QMS on construction projects is customer's satisfaction, and also its total mean values was 3.86, and close to a rate of 4 (Agree). Ranked second is cost as one of organization objectives, the total mean scores was 3.65, and close to a rate of 4 (Agree), and is found to be important and effective in reducing expenses of construction project through QMS implementation. In terms of the impact of QMS on time, as one of the internal criteria of project success, was ranked number three with total mean value of 3.61, and close to a rate of 4 (Agree). Finally, the lowest ranking was belonged to the quality/scope with total average of 3.51, and close to a rate of 4 (Agree), which proved that QMS can affect least influence on quality/scope in contrast with other vital criteria in construction projects of ISO 9001-certified firms in Metro Manila, Philippines.

Table 12. Summary of the effects of QMS on critical factors of the construction project based on mean scores

\begin{tabular}{|c|c|c|c|c|c|}
\hline No. & Criterion & $\begin{array}{c}\text { Average } \\
\text { Index }\end{array}$ & SD & Remarks & Rank \\
\hline \multicolumn{6}{|c|}{ Internal criteria of project success (Organization objective) } \\
\hline 1 & Quality/Scope & 3.51 & 1.4092 & Agree & 4 \\
\hline 2 & Time & 3.61 & 1.326 & Agree & 3 \\
\hline 3 & Cost & 3.65 & 1.322 & Agree & 2 \\
\hline \multicolumn{6}{|c|}{ External criteria of project success (Business objective) } \\
\hline 4 & Customer's satisfaction & 3.86 & 1.288 & Agree & 1 \\
\hline
\end{tabular}

\section{CONCLUSIONS}

In this study, literature review unearthed that the implementation of QMS can be an effective technique to achieve the objectives of projects successfully through process approach, which is based on "PDCA" methodology towards the optimization of project performance, and problem solving. From literature review, it was revealed that project success is the most efficient key to assess projects in construction industry, and the customer's satisfaction as business objectives, and iron triangle (cost, time, quality) are the most significant elements in success of construction projects according to scholars. Furthermore, the results of the study from the responses of 37 managers, have been identified that QMS can be affected mostly on customer's satisfaction. It may be justified that the impact of QMS on customer's satisfaction is more than other vital criteria in construction projects, because process approach of QMS is considered and prioritized the customer's requirements and satisfaction, as its input and output in the organizations. Likewise, QMS can affect directly and indirectly on cost and time in the projects, while the lowest impact of QMS is on 
quality/scope. Unfortunately, the results reported that the most of the managers emphasized on implementing QMS certification (ISO 9001 certification) only, and often neglect to use other standards of QMS. While the implementation of all standards of QMS can even improve incrementally quality/scope, reduce the cost and time length of the construction projects, and promote customer's satisfaction. However, the study concluded that QMS is an appropriate quality management and marketing tools for developing and improving organization performance. In this context it is suggested to implement QMS standard in the projects to improve organization performance. For future research, the study suggests to identify the best ways for the sustainable development of construction projects from the perspective of implementation of a QMS.

\section{REFERENCES}

Alberto D. M. (2011) Project Management for Facility Constructions: A Guide for Engineers and Architects. Heidelberg, New York: Springer-Verlag. (ISBN 978-3-642-17091-1).

Aized, T. (2012). Total Quality Management and Six Sigma. Rijeka, Croatia: InTech. (ISBN 978-953-51-0688-3).

Ali, A and Rahmat, H. (2010). The performance measurement of construction projects managed by ISO-certified contractors in Malaysia. Journal of Retail \& Leisure Property, 2010, 9(1), pp. 25-35.

Duggal, J. (2010). Next Level Up:How Do You Measure Project Success? Rethinking the Triple Constraint. Retrieved from http://www.pmi.org/Learning/next-level-up-how-do-you-measure-project-success.aspx (Accessed in 2010, July 9).

Enshassi, A., Arain, F., and El-Rayyes, Y. (2014). Post-evaluation System in Construction Projects in Gaza StripPalestine. Journal of Construction in Developing Countries, 2014, 19(2), pp. 51-73.

Golob, K., Bastič, M. and Pšunder, I. (2013). Influence of Project and Marketing Management on Delays, Penalties, and Project Quality in Slovene Organizations in the Construction Industry, Journal of Management in Engineering, 29(4), October 2013, pp. 495-502.

Hajiagha, H. Akrami, H. Hashemi, S. and Mahdiraji, H. (2015). An Integer Grey Goal Programming For Project Time, Cost and Quality Trade-Off. Inzinerine Ekonomika-Engineering Economics, 2015, 26(1), pp. 93-100.

IAF (2015). Transition Planning Guidance for ISO 9001:2015. International Accreditation Forum, Inc. Retrieved from http://www.iso.org/iso/iafid9transition9001publicationversion.pdf (Accessed in 2015, January 12).

ISO (2008). ISO 9000 Introduction and Support Package: Guidance on the Concept and Use of the Process Approach for management $\quad$ systems. Retrieved from http://www.iso.org/iso/04_concept_and_use_of_the_process_approach_for_management_systems.pdf (Accessed in 2014, August 19).

ISO (2009). Selection and use of the ISO 9000 family of standards. Retrieved from http://www.iso.org/iso/iso_9000_selection_and_use-2009.pdf (Accessed in 2014, April 3).

ISO (2010). ISO 9001 for Small Business: What to do (Advice from ISO/TC 176). ISO, Geneva, Switzerland. (ISBN 978-92-67-10516-1).

ISO (2012). ISO 9000:2005 Quality management systems - Fundamentals and vocabulary, ${ }^{\text {th }}$ ed. ISO, Geneva, Switzerland. (ISBN 978-92-67-10573-4).

ISO (2014). The ISO Survey of Management System Standard Certifications. Retrieved from 2014 http://www.iso.org/iso/iso_survey_executive-summary.pdf?v2014 (Accessed in 2014).

ISO (2015a). Moving from ISO 9001:2008 to ISO 9001:2015. ISO, Geneva, Switzerland. (ISBN 978-92-67-10646-5).

ISO (2015b). ISO 9001: Debunking the myths. ISO, Geneva, Switzerland.(ISBN 978-92-67-10639-7).

ISO (2015c). 9000: 2015: Quality management principles. ISO, Geneva, Switzerland. (ISBN 978-92-67-10650-2).

ISO (2015d). THE PROCESS APPROACH IN ISO 9001:2015. ISO, Geneva, Switzerland.

ISO (2015e). ISO 9001: Reaping the benefits of ISO 9001. ISO, Geneva, Switzerland. (ISBN 978-92-67-10641-0).

Juran, M., and Godfrey, A. (1999). Juran's quality handbook (5 ${ }^{\text {th }}$ ed.). Washington, D.C.: McGraw-Hill Companies, Inc. (ISBN 0-07-034003-X).

Kerzner, H. (2010). PROJECT MANAGEMENT: A Systems Approach to Planning, Scheduling, and Controlling (10 $\stackrel{\text { th }}{-}$ ed.). Hoboken, New Jersey: John Wiley \& Sons, Inc., ISBN 978-0-470-27870-3.

Khattak, A. and Arshad, M. (2015). Barricades in Implementation and Adoptation Level of ISO-9001

in Construction Industry of Pakistan. European Journal of Business and Management, 2015, 7(13), pp. 203-11.

Kuen, C. and Zailani, S. (2007). FACTORS INFLUENCING THE SUCCESS OF PROJECT MANAGEMENT AMONGST MANUFACTURING COMPANIES IN MALAYSIA: A CONCEPTUAL FRAMEWORK. Proceedings of the $7^{\text {th }}$ Global Conference on Business \& Economics, October 13-14, 2007, Rome, Italy.

Neyestani, B., \& Juanzon, J. B. P. (2016). Identification of A Set of Appropriate Critical Success Factors for Successful TQM Implementation in Construction, and Other Industries. International Journal of Advanced Research, 4(11), pp. 1581-1591.

Mane, P. And Patil J. (2015). Quality Management System at Construction Project: A Questionnaire Survey. Journal of Engineering Research and Applications, 5(3), ( Part -3), pp.126-130. 
Madsen, S. (2013). Is the iron triangle outdated? Retrieved from http://www.susannemadsen.co.uk/blog/the-irontriangle-and-the-tripleconstraintsare-outdated (Accessed in 2013, Dec 12).

Neverauskas, B., Bakinaite, L., and Meiliene, E. (2013). CONTEMPORARY APPROACH TO THE POSSIBILITY OF PROJECT'S SUCCESS INCREASE. ECONOMICS AND MANAGEMENT JOURNAL, 18 (4), pp. 829836.

Neyestani, B. (2016). Impact of ISO 9001 Certification on the Projects' Success of Large-Scale (AAA) Construction Firms in the Philippines. International Research Journal of Management, IT and Social Sciences, 3(11), pp. $35-45$.

Neyestani, B., \& Juanzon, J. B. P. (2016). Identification of A Set of Appropriate Critical Success Factors (CSFs) for Successful TQM Implementation in Construction, and Other Industries. International Journal of Advanced Research, 4(11), pp. 1581-1591.

Neyestani, B., \& Juanzon, J. B. P. (2016a). Developing an Appropriate Performance Measurement Framework for Total Quality Management (TQM) in Construction and Other Industries. IRA-International Journal of Technology \& Engineering, 5(2), pp. 32-44.

Proust, E. (2011). How to achieve success in iconic construction projects: the iron triangle hegemony challenged (A Master's Thesis), Chalmers, Göteborg, Sweden.

PMI. (2008). A GUIDE TO THE PROJECT MANAGEMENT BODY OF KNOWLEDGE (PMBOK) (4 ${ }^{\text {th }}$ ed.). Newtown Square, Pensylvania: PMI, Inc., ISBN:978-1-933890-51-7.

Rasmy, M. H., Abdelsalam, H. M., \& Ragab, R. (2008). Multi-objective Optimization of Time-Cost Trade-Off Analysis in Critical Chain Project Management Networks Using Pareto Simulated Annealing. Proceedings of 6th International Conference on Informatics and Systems (INFOS), Cairo, Egypt March 27-29, 2008.

Rezaian, A. (2011). Time-Cost-Quality-Risk of Construction and Development Projects or Investment. Middle-East Journal of Scientific Research, 2011, 10 (2), pp. 218-223.

Singh, A. and Khanduja, D. (2014) Defining Quality Management in Auto Sector: A Six Sigma Perception. Procedia Materials Science of Elsevier, 2014, 5(2014), pp. 2645-2653.

Tabish, Z. and Jha, K. (2012). Success Traits for a Construction Project. JOURNAL OF CONSTRUCTION ENGINEERING AND MANAGEMENT, 2012, Oct 1, 138(10), pp. 1131-1138.

Tarí, J., Azorín, J., Heras, I. (2012). Benefits of the ISO 9001 and ISO 14001 standards: A literature review. Journal of Indusrial Engineering and Management, 2012, 5(2), pp. 297-322.

Thilakarathne, P. and Chithrangani, S. (2014). A study on analysis of managerial attitudes towards ISO 9001: 2008 quality management system introduction and implementation process in Sri Lanka. International Journal of Economics, Finance and Management Sciences, 2014; 2(2), pp. 123-131, doi: 10.11648/j.ijefm.20140202.12.

UNIDO (2012). ISO 9001 - Its relevance and impact in Asian Developing Economies. Based on Project TE/RAS/09/003: A survey covering quality management system development, certification, accreditation and economic benefits, United Nations Industrial Development Organization, Retrieved from https://www.unido.org/fileadmin/user_media/Publications/Pub_free/ISO\%209001\%20Impact\%20SurveyeBook_ver2.pdf (Accessed in 2012, April).

Varajão, J., Dominguez, C., Ribeiro, P., and Paiva, A. (2014). CRITICAL SUCCESS ASPECTS IN PROJECT MANAGEMENT: SIMILARITIES AND DIFFERENCES BETWEEN THE CONSTRUCTION AND THE SOFTWARE INDUSTRY. Tehnički vjesnik Journal, 2014, 21(3), pp. 583-589.

Zwikael, O., and Smyrk, J. (2011). Project Management for the Creation of Organisational Value. (1 ${ }^{\text {st }}$ ed.). Dordrecht, London: Springer-Verlag. (ISBN 978-1-84996-515-6). 